\title{
Ascorbate status and fibrinogen concentrations after cerebrovascular accident
}

\author{
R HUME, BD VALLANCE, MM MUIR \\ From the Medical Division, Southern General Hospital, Glasgow G51 4TF
}

SUMMARY Leucocyte ascorbate (LA) and serum ascorbate (SA) were measured in patients who had sustained an acute cerebrovascular accident. There was a significant fall in LA and SA within 24 hours of the incident and this persisted for several weeks. The "stress" of the event resulted in a rise in serum cortisol concentration and depletion of both pituitary and adrenal glands of ascorbate when examined at post mortem. Serum fibrinogen concentrations also rose above normal.

The role of ascorbate in pituitary and adrenal function and the relation of ascorbate to acute and chronic vascular disorders has still to be established.

It has been previously shown that after an acute myocardial infarction (MI) there is a significant fall in both leucocyte ascorbate (LA) and serum ascorbate (SA) and that this depletion will last for at least two months. ${ }^{12}$ It is not known whether these changes in LA and SA are specific for patients who have sustained an acute myocardial infarction.

It was decided therefore that the LA and SA status of patients who had sustained acute cerebrovascular accidents should be studied in a like manner to see if a similar pattern emerged. Opportunity was also taken to compare the ascorbate content of brain tissue obtained from patients who had died from cerebrovascular accident with that of brain tissue obtained from patients who had died from other causes. Since there is an inverse relation between the adrenal content of ascorbate and the increased activity of the gland in states of stress, ${ }^{3}$ adrenal gland tissue was also examined for its ascorbate content.

\section{Patients and methods}

\section{PATIENTS}

Twenty-five patients (11 men, 14 women) who had sustained an acute cerebrovascular accident were studied. The mean age was $67 \pm 10 \mathrm{yr}$. Ten patients were seen on the first day of the accident. Observations were made daily for the next 10 days and although it was not possible to make daily observations on each patient over the ten day period, 10

Accepted for publication 6 July 1981 observations were available for analysis each day. The results from four patients who died within four days of their acute cerebrovascular accident were analysed separately. The mean age of this group was $71 \pm 12 \mathrm{yr}$. The results from the one patient who died within 48 hours was also analysed separately.

\section{CONTROL SUBJECTS}

These consisted of 12 patients ( 6 men, 6 women) aged $60 \pm 13 \mathrm{yr}$, who had been admitted to the same wards with illnesses other than cerebrovascular accident, heart attacks or patients with known dietary deficiencies. There was no significant age difference between the patients and the controls.

Leucocyte ascorbate $\left(\mathrm{nmol} / 10^{8} \mathrm{WBC}\right)$ was measured by the method of Bessey et $\mathrm{al}^{4}$ as modified by Denson and Bowers. ${ }^{5}$

Serum ascorbate $(\mu \mathrm{mol} / \mathrm{l})$ was measured by the method of Denson and Bowers. ${ }^{5}$

Plasma cortisol concentrations (nmol/l) were measured by the method of Mattingly. ${ }^{6}$

Total white cell counts $\left(\times 10^{9} / 1\right)$ were performed by a Coulter counter.

Plasma fibrinogen concentrations $(\mathrm{g} / \mathrm{l})$ were measured by means of a nephelometer.

NECROPSY MATERIAL

Ascorbate was estimated in samples of brain taken from patients who had died from cerebrovascular accident ( 5 men, 4 women) their mean age being $64 \pm 14 \mathrm{yr}$ and compared with the ascorbate content of the brain obtained from patients who 
have died from other causes, excluding vascular causes ( 9 men, 5 women). Their mean age was $72 \pm 6$ yr. There was no significant age difference between the groups.

The brain sample was taken from the undamaged hemisphere with the exception of one specimen where both hemispheres were sampled. Samples of brain were taken from the grey matter, white matter and the pituitary gland. The ascorbate content of the adrenal glands of the same subjects were also measured. Approximately 0.1 to $0.2 \mathrm{~g}$ of wet brain or adrenal gland accurately weighed were used in the estimations. These extracts were made by modification of the method of Sayers and Woodbury? using a $5 \%$ instead of a $4 \%$ trichlorocetic acid solution as the extraction and a Silverson mixer to homogenise the sample. Part of the clear filtrate $(1.0 \mathrm{ml})$ was treated as for serum ascorbate by the method of Denson and Bowers. ${ }^{5}$ The results were expressed as $\mathrm{mg} / \mathrm{kg}$ wet tissue.

\section{Results}

LEUCOCYTE ASCORBATE (LA) (Table 1)

The mean leucocyte ascorbate in the 10 patients measured within 24 hours of the onset of the cerebrovascular accident was $79 \pm 31 \mathrm{nmol} / \mathrm{WBC}$ which is significantly less than the 12 control patients, $159 \pm 62 \mathrm{nmol} / 10^{8}$ WBC $(\mathrm{p}<0.01)$. Depressed concentrations of LA varying from 78 to $107 \mathrm{nmol} / 10^{8} \mathrm{WBC}$ persisted for the next 10 days ( $p<0.01$ ). Two months later although only four observations were available for analysis, the level was still low at $90 \pm 8 \mathrm{nmol} / 10^{8} \mathrm{WBC}$. Analysis of the four patients who died within four days of the acute cerebrovascular accident revealed a very low concentration of LA $32 \pm 17 \mathrm{nmol} / 10^{8}$ WBC $(\mathrm{p}<0.01)$. The patient who died within two days had an LA concentration of $19 \mathrm{nmol} / 10^{8} \mathrm{WBC}$.

SERUM ASCORBATE (SA) (Table 1)

The mean serum ascorbate in the 10 patients measured within 24 hours of the onset of the cerebrovascular accident was $16 \pm 10 \mu \mathrm{mol} / 1$ which is significantly less than the SA of the 12 control patients $34 \pm 18 \mu \mathrm{mol} / 1 \quad \mathrm{p}<0.05)$. Depressed concentrations varying from 13 to $17 \mu \mathrm{mol} / 1$ persisted for the next 10 days $(\mathrm{p}<0.05)$. Two months later, although only four observations were available for analysis, showed that the serum SA was still very low being $16 \pm 6 \mu \mathrm{mol} / 1$. Analysis of the four patients who died within four days of the cerebrovascular accident revealed a very low concentration of SA $10 \pm 5 \mu \mathrm{mol} / 1(\mathrm{p}<0.02)$. The patient who died within two days had an SA of $6 \mu \mathrm{mol} / 1$.

\section{CORTISOL (Table 1)}

The mean plasma cortisol concentration in the 10 patients measured within 24 hours of the onset of acute cerebrovascular accident was $903 \pm 587 \mathrm{nmol} / \mathrm{l}$ which although raised was not significantly different from the controls $556 \pm 176 \mathrm{nmol} / \mathrm{l}(\mathrm{p}>0.05)$. On the second day the cortisol concentration had returned to a lower level of $592 \pm 208 \mathrm{nmol} / \mathrm{l}$ and remained so throughout the period of the study.

Analysis of the four patients who died within four days of the acute cerebrovascular accident revealed a cortisol concentration of $1239 \pm$ $384 \mathrm{nmol} / \mathrm{l}$ which was significantly different from normal $(\mathrm{p}<0.01)$. The patient who died within two days had a cortisol concentration of $1468 \mathrm{nmol} / \mathrm{l}$.

FIBRINOGEN (Table 1)

The mean plasma fibrinogen concentration of 10 patients seen within 24 hours of the onset of the cerebrovascular accident was $3.48 \pm 0.51 \mathrm{~g} / \mathrm{l}$ which is significantly higher than the controls at $2.84 \pm$ $0.85 \mathrm{~g} / \mathrm{l}(\mathrm{p}<0.05)$. The fibrinogen concentrations remained persistently higher than those in control subjects throughout the period of the study. Analysis of the four patients who died within four days of the acute cerebrovascular accident was significantly raised at $6.4 \pm 3.7 \mathrm{~g} / \mathrm{l}(\mathrm{p}<0.02)$. The patient who died within two days had a fibrinogen concentration of $6.04 \mathrm{~g} / \mathrm{l}$.

Table 1 Composite data of blood analysis (mean $\pm S D$ ) in 25 patients and 12 controls

\begin{tabular}{|c|c|c|c|c|c|c|c|}
\hline & \multicolumn{7}{|c|}{ Days after cerebrovascular accident } \\
\hline & $\begin{array}{l}1 \\
n=10\end{array}$ & $\frac{2}{n}=10$ & $\begin{array}{l}3 \\
n=10\end{array}$ & $\begin{array}{l}4 \\
n\end{array}=10$ & $\begin{array}{l}5 \\
n=10\end{array}$ & $\begin{array}{l}6 \\
n=10\end{array}$ & $n=10$ \\
\hline $\begin{array}{l}\text { Leucocyte ascorbate (nmol/108 } 0^{8} \text { WBC) } \\
\text { Serum ascorbate ( } \mu \mathrm{mol} / \mathrm{l}) \\
\left.\text { WBC ( } 10^{9} / \mathrm{l}\right) \\
\text { Fibrinogen }(\mathrm{g} / \mathrm{l}) \\
\text { Cortisol }(\mathrm{nmol} / \mathrm{l}) \\
\text { Age (yr) }\end{array}$ & $\begin{array}{l}79 \pm 31 \\
16 \pm 10 \\
8 \cdot 7 \pm 1 \cdot 3 \\
3 \cdot 48 \pm 0 \cdot 51 \\
903 \pm 587 \\
67 \pm 10\end{array}$ & $\begin{array}{l}78 \pm 19 \\
15 \pm 8 \\
8 \cdot 6 \pm 1 \cdot 5 \\
3 \cdot 74 \pm 0 \cdot 8 \\
592 \pm 208\end{array}$ & $\begin{array}{l}80 \pm 24 \\
14 \pm 8 \\
10 \pm 1 \cdot 9 \\
3 \cdot 78 \pm 0 \cdot 45 \\
634 \pm 148\end{array}$ & $\begin{array}{l}79 \pm 35 \\
14 \pm 9 \\
7 \cdot 4 \pm 2 \cdot 0 \\
4 \cdot 1 \pm 0 \cdot 75 \\
449 \pm 187\end{array}$ & $\begin{array}{l}81 \pm 33 \\
14 \pm 7 \\
8 \cdot 1 \pm 3 \cdot 4 \\
3 \cdot 77 \pm 0 \cdot 63 \\
614 \pm 214\end{array}$ & $\begin{array}{l}84 \pm 25 \\
13 \pm 5 \\
7 \cdot 9 \pm 1 \cdot 3 \\
3 \cdot 65 \pm 0 \cdot 4 \\
591 \pm 348\end{array}$ & 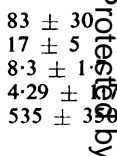 \\
\hline
\end{tabular}


Table 2 Brain, adrenal, and pituitary tissue ascorbate content ( $\mathrm{mg} / \mathrm{kg}$ wet tissue) in 9 patients and 14 controls

\begin{tabular}{|c|c|c|c|c|c|c|}
\hline & \multirow[t]{2}{*}{ No of subjects } & \multirow[t]{2}{*}{ Age $(y r)$} & \multicolumn{2}{|l|}{ Brain } & \multirow[t]{2}{*}{ Adrenal gland } & \multirow[t]{2}{*}{ Pituitary gland } \\
\hline & & & Grey & White & & \\
\hline $\begin{array}{l}\text { Cerebrovascular } \\
\text { accidents } \\
\text { Death within two days }\end{array}$ & $\begin{array}{l}5 \mathrm{M} \\
4 \mathrm{~F} \\
1 \mathrm{M}\end{array}$ & $\begin{array}{l}64 \pm 14 \\
60\end{array}$ & $\begin{array}{l}183 \pm 52 \\
117\end{array}$ & $\begin{array}{l}143 \pm 33 \\
117\end{array}$ & $\begin{array}{l}291 \pm 126 \\
187\end{array}$ & $\begin{array}{l}294 \pm 126 \\
184\end{array}$ \\
\hline Controls & $\begin{array}{l}9 \mathrm{M} \\
5 \mathrm{~F}\end{array}$ & $72 \pm 6$ & $199 \pm 45$ & $155 \pm 30$ & $374 \pm 127$ & $428 \pm 145$ \\
\hline
\end{tabular}

RELATION BETWEEN ASCORBATE CONTENT OF THE BRAIN TISSUE AND ADRENAL GLANDS FROM PATIENTS DYING OF CEREBROVASCULAR ACCIDENT AND THOSE DYING WITH OTHER CONDITIONS

(Table 2)

There were nine samples from the undamaged hemisphere from patients who had died from cerebrovascular accident and similar samples from 14 patients who had died with other conditions. Samples were obtained from the grey matter, white matter, pituitary glands and adrenal glands for comparison. Analysis revealed that in both "cerebrovascular accident" and "other" samples the amount of ascorbate was greater in the grey matter $(183 \pm 52$, $199 \pm 45 \mathrm{mg} / \mathrm{kg}$ respectively) than in the white matter $(143 \pm 33,155 \pm 30 \mathrm{mg} / \mathrm{kg}$ respectively) ( $<<0.005$ ) and that the ascorbate content of the adrenal glands $(291 \pm 126,374 \pm 127 \mathrm{mg} / \mathrm{kg}$ respectively) and pituitary glands (294 \pm 126 , $428 \pm 145 \mathrm{mg} / \mathrm{kg}$ respectively) for both groups were significantly greater than either the white matter or the grey matter $(p<0.02)$. In the "cerebrovascular accident" samples there were no significant differences between the ascorbate content of the pituitary and adrenal gland. In the "other" samples, there was a significant increase in ascorbate in the pituitary as compared to the adrenals ( $p<0.02$ ).

Between group analysis revealed that there were no significant differences between the ascorbate content of the grey matter or white matter in the two groups. There was significantly more ascorbate in the pituitary glands of the control subjects than the cerebrovascular accident patients $(p<0.02)$ and similarly in the adrenal glands $(\mathrm{p}<0.05)$.
It was possible to analyse only one brain from a "cerebrovascular" patient in whom also the LA, SA, cortisol and fibrinogen concentrations were measured. This patient died within two days of the acute cerebrovascular condition. The results in this patient revealed the lowest concentrations of ascorbate and the highest of cortisol, fibrinogen and WBC in the whole study (Table 1).

\section{Discussion}

Within 24 hours of a cerebrovascular accident, the mean leucocyte ascorbate (LA) (79 $\mathrm{nmol} / 10^{8}$ WBC) was singificantly reduced to half that of the controls (159 $\mathrm{nmol} / 10^{8} \mathrm{WBC}$ ) and remained so for the next 10 days. Two months later, although there were only four observations, the mean concentration was still very low at $90 \mathrm{nmol} / 10^{8} \mathrm{WBC}$. A similar pattern was observed with regard to the mean serum ascorbate (SA) $(16 \mu \mathrm{mol} / \mathrm{l})$ as compared to the mean control concentration (34 $\mu \mathrm{mol} / \mathrm{l}$ : $\mathrm{p}<0.05)$. Two weeks later the mean level was still $16 \mu \mathrm{mol} / \mathrm{l}$.

It was interesting to note that the four patients who died within four days of their cerebrovascular accident had a more severe reduction still in mean LA (32 nmol/108 WBC) and mean SA (10 $\mu \mathrm{mol} / \mathrm{l})$. The "stressfulness" of the deaths of this group of four patients is also reflected in the raised mean concentration of cortisol which was $1239 \mathrm{nmol} / \mathrm{l}$ compared to $903 \mathrm{nmol} / \mathrm{l}$ for the group of "cerebrovascular" patients as a whole and significantly greater than the mean control concentration of $556 \mathrm{nmol} / \mathrm{l}(\mathrm{p}<0.01)$.

In keeping with the raised concentrations of

\begin{tabular}{|c|c|c|c|c|c|c|}
\hline & & & & Controls & Death within four days & Death within two days \\
\hline $\begin{array}{l}8 \\
n=10\end{array}$ & $\begin{array}{l}9 \\
n=10\end{array}$ & $\begin{array}{l}10 \\
n=10\end{array}$ & $\begin{array}{l}56 \\
n=4\end{array}$ & $n=12$ & $n=4$ & $n=1$ \\
\hline $\begin{array}{l}107 \pm 33 \\
16 \pm 6 \\
7 \cdot 1 \pm 1 \cdot 9 \\
3 \cdot 63 \pm 0 \cdot 55 \\
531 \pm 210\end{array}$ & $\begin{array}{l}87 \pm 30 \\
15 \pm 8 \\
7 \cdot 9 \pm 2 \cdot 4 \\
3 \cdot 8 \pm 1 \cdot 02 \\
505 \pm 147\end{array}$ & $\begin{array}{l}86 \pm 35 \\
14 \pm 6 \\
8 \cdot 7 \pm 2 \cdot 8 \\
4 \cdot 03 \pm 1 \cdot 1 \\
533 \pm 226\end{array}$ & $\begin{array}{l}90 \pm 8 \\
16 \pm 6 \\
7 \pm 1 \cdot 0 \\
4 \cdot 34 \pm 0 \cdot 85 \\
477 \pm 155\end{array}$ & $\begin{array}{l}159 \pm 62 \\
34 \pm 18 \\
6 \cdot 3 \pm 2 \cdot 1 \\
2 \cdot 84 \pm 0 \cdot 85 \\
556 \pm 176 \\
60 \pm 13\end{array}$ & $\begin{array}{l}32 \pm 17 \\
10 \pm 5 \\
11 \cdot 1 \pm 3 \cdot 0 \\
6 \cdot 4 \pm 3 \cdot 7 \\
1239 \pm 384 \\
71 \pm 12\end{array}$ & $\begin{array}{l}19 \\
6 \\
15 \cdot 1 \\
6 \cdot 04 \\
1468 \\
54\end{array}$ \\
\hline
\end{tabular}


cortisol there was a significant rise in the mean white cell counts $(p<0.05)$.

The patient who was most critically ill and died within 48 hours of his cerebrovascular accident revealed the most severe changes in SA $(6 \mu \mathrm{mol} / \mathrm{l})$, in LA $\left(19 \mathrm{nmol} / 10^{8} \mathrm{WBC}\right)$, in cortisol $(1468 \mathrm{nmol} / \mathrm{l})$, in WBC count $\left(15.1 \times 10^{9} / 1\right)$ and in fibrinogen concentration $(6.06 \mathrm{~g} / \mathrm{l})$. Analysis of this patient's brain tissue which will be discussed later also showed the most striking results. These findings are similar in pattern to those found in patients who have suffered an acute myocardial infarction. ${ }^{12}$ However, as reflected by the cortisol concentrations, patients who survive a cerebrovascular accident are much less severely "stressed" than those who survive an acute myocardial infarction. ${ }^{1}$

The results also confirm that after a vascular catastrophe plasma fibrinogen concentrations rise markedly ${ }^{8-10}$ above the level expected from the increase which occurs with age. ${ }^{10}$ The relation between the level of fibrinogen and vascular disease remains obscure. ${ }^{11}$

The analysis of the brain tissue and adrenal glands revealed that in general there is significantly more ascorbate in the grey matter than in the white matter of the brain $(p<0.005)$. This is perhaps not surprising since the grey matter contains cells as opposed to the axons of the white matter. Also the pituitary and adrenal glands contain significantly more ascorbate than either the grey matter or the white matter $(p<0.05)$ and that normally the pituitary gland contains significantly more ascorbate than the adrenal gland $(\mathrm{p}<0.02)$. This relation between the pituitary and adrenal glands has previously been studied. ${ }^{12}$ A similar pattern exists for the undamaged hemispheres of the infarcted brains with the exception that the pituitary gland ascorbate content is not significantly different from that of the adrenal gland. This is due to the fact that the pituitary gland of the infarcted brains has been significantly depleted of ascorbate relative to the adrenals $(\mathrm{p}<0.02)$ but that that adrenal glands are also depleted is shown by the fact that the ascorbate content is less than that of the adrenal glands from "other" deaths $(p<0.05)$.

Analysis of the brain of the patient who died within 48 hours of the onset of cerebrovascular accident and who had the most severe depletion of SA and LA revealed that there were very low concentrations of ascorbic acid in the grey matter and white matter as compared to the mean concentrations found in the "other" brains and the "cerebrovascular" brains as a whole. However the samples of brain tissue which were taken from the infarcted side, away from the actual haemorrhage, produced reasonable concentrations of ascorbate in the grey matter and in the white matter. This might reflect a mobilisation of ascorbate to the infarcted side of the brain similar to that found in the case of the infarcted myocardium. ${ }^{1}$

The pituitary and adrenal glands of this patient also had very low concentrations of ascorbate as compared to the mean ascorbate content of the adrenal and pituitary glands of both the "cerebrovascular" patients and the "other" patients. It has previously been shown that there is an inverse relation between the amount of ascorbic acid in the adrenal gland and the increased activity of the gland in states of "stress" 3 although there is doubt as to the precise role of ascorbate in steroid metabolism. ${ }^{13}$ These results again reflect that the greater the "stress" the more the adrenal and pituitary glands become depleted of ascorbate and perhaps even the brain tissue in general.

It is now clear that after a vascular catastrophe such as a myocardial infarction or an acute cerebrovascular accident there is depletion of body ascorbate as reflected in the low SA and LA and that the pituitary and adrenal glands are similarly affected. What is less clear is whether this depletion results in a suboptimal response to "stress" and whether, in the longer term, healing may be adversely affected. This study along with those on patients with acute myocaridal infarction suggests that the relation of ascorbate to acute and chronic vascular events requires further investigation.

We wish to thank Dr GH Roberts, Department of Pathology, for supplying the necropsy tissue.

\section{References}

${ }^{1}$ Hume R, Weyers E, Rowan T, Reid DS, Hillis WH. Leucocyte ascorbic acid levels after acute myocardial infarction. Br Heart $J$ 1972;34:328.

2 Vallance B, Hume R, Weyer E. The reassessment of the changes in the leucocyte and serum ascorbic acid following acute myocardial infarction. $\mathrm{Br}$ Heart $J$ 1978;40:64.

${ }^{3}$ Booker WM, DaCosta EM, Tureman JR, Froix C, Jones $\mathrm{W}$. The relation of ascorbic acid to adrenocortical function during cold stress. Endocrinology 1955;56:413.

${ }^{4}$ Bessey OA, Lowry OH, Brock MJ. Quantitative determination of AA in small amounts of WBCs and platelets. J Biol Chem 1947;168:179-205.

${ }^{5}$ Denson KW, Bowers EF. The distribution of ascorbic acid in white blood cells: a comparison of WBC, ascorbic acid and phenolic acid excretion in elderly patients. Clin Sci $1961 ; 21: 157$.

- Mattingly D. A simple fluorimetric method for the estimation of free 11-hyroxycorticoids in human plasma. $J$ Clin Pathol 1962;25:374.

' Sayers MA, Sayers G, Woodbury LA. Assay of ACTH by adrenal AA depletion method. Endocrinology 1948; 42:379.

${ }^{8}$ Gilchrist E, Tulloch JA. Observations on plasma fibrino- 
gen content after MI. Edinburgh Medical Journal 1952;59:561-7.

${ }^{9}$ Losner S, Volk BW, Willensky ND. Fibrinogen concentration in acute MI comparison of clot density deterioration of fibrinogen with ESR. Ann Intern Med 1954; 93:231-45.

${ }^{10}$ Hume $R$. The relationship to age and cerebral vascular accidents of fibrin and fibrinolytic activity $J$ Clin Pathol 1961;14:167.

${ }^{11}$ Lowe GDO, Forbes $\mathrm{CD}$. The plasma fibrinogen level and vascular diseases. Scott Med J 1981; S29-Proceedings of a Symposium held in Malmö, Sweden, 1980.

12 Gough J. Vitamin C in human pituitary. Lancet 1934; 1279.

${ }^{13} \mathrm{Kitabchi}$ AE. Ascorbic acid in steroidogenesis. Nature 1967;215:1385.

Requests for reprints to: Dr R Hume, Southern General Hospital, Glasgow G51 4TF, Scotland.

\section{The January 1982 Issue}

\section{THE JANUARY 1982 ISSUE CONTAINS THE FOLLOWING PAPERS}

\section{Review article}

Cervical intraepithelial neoplasia CH BUCKLEY, EB BUTLER, H FOX

Immunoperoxidase study of the secretory immunoglobulin system in colonic neoplasia P ISAACSON

Morphological and mucus secretion criteria for differential diagnosis of solitary ulcer syndrom and non-specific proctitis M EHSANULLAN, MI FILIPE, B GAZZARD

Principal neuropathological and general necropsy findings in 24 renal transplant patients R MORTON, DI GRAHAM, JD BRIGGS, DNH HAMILTON

Computer programs in histopathology record keeping KV SWETTENHAM, C NICKOLS, CL BERRY

Comparative study between biochemical and histological methods and image analysis in liver iron overload $Y$ DEUGNIER, $S$ MARGULES, $P$ BRISSOT, MA DEUGNIER, JC BISCONTE, M BOUREL, B FERRAND

Investigation into paediatric bilirubin analyses in Australia and New Zealand LR WATKINSON, A ST JOHN, LA PENBERTHY

Applicability and significance of salicylate screening in sera of voluntary blood donors: evaluation of two analytical methods R SHARON, I FRUTKOFF, G KIDRONI, J MENCZEL

Monoclonal gammopathies in the adult population of Finistère, France JP SALEUN, $M$ VICARIOT, P DEROFF, JF MORIN

A pilot study of the reference values for the commoner haematological and biochemical parameters in Saudi nationals T GILBERT SCOTT
${ }^{111}$ Indium-labelled white blood cells in the diagnosis of Felty's syndrome GG BIRNIE, AS EADIE, CJ HOSIE, NP LUCIE, G WATKINSON

Reaction of the human granulocyte system in successfully treated bacterial bronchopneumonia J KRUSZEWSKI, C SZCZYLIK, W WIKTOR-JEDRZEJCZAK

The United Kingdom national microbiological quality assessment scheme JJS SNELL, JV DE MELLOW, PS GARDNER

System for laboratory proficiency testing in bacteriology: organisation and impact on microbiology laboratories in health care facilities funded by the Ontario Government JL WHITBY, WA BLACK, H RICHARDSON, DE WOOD

Enzyme-linked immunosorbent assay for the diagnosis of recent rubella infection YS LIM, CC LAM, SK LAM

Comparison of ELISA, SPACE, and electron microscopy for the routine diagnosis of rotavirus infection RA WALL, BJ MELLARS, P LUTON, S BOULDING

Evaluation of the Lumac kit for the detection of bacteriuria by bioluminescence $\mathrm{D}$ MACKETT, $\mathrm{S}$ KESSOCK-PHILIP, S BASCOMB, CSF EASMON

\section{Technical Methods}

Demonstration of immunoproteins in aralditeembedded tissues JUNE GIDDINGS, RL GRIFFIN, AG MaCIVER

A rapid and accurate differential centrifugation method for platelet counts S COUSINS, SM LEWIS

\section{Letters to the Editor}

\section{Book Reviews}

Copies are still available and may be obtained from the PUBLISHING MANAGER, BRITISH MEDICAL ASSOCIATION, TAVISTOCK SQUARE, LONDON WC1H 9JR, price $£ 3.00$, including postage 